\title{
Past Conferences
}

\section{Rethymno, Crete}

\section{9-11 December 2003}

An international conference was held in Rethymno, Crete, on 9-11 Decem-

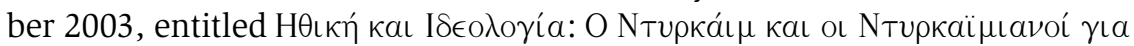

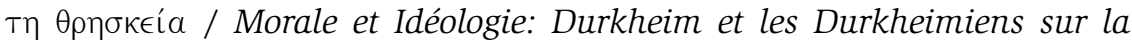
religion. It was officially in Greek and French, but English was also spoken, and thanks are due to the team who, in providing a simultaneous translation, switched between the three languages. Thanks are not least due to the conference's organizers, led by Myron Achimastos, the Department of Sociology, the University of Crete. The hospitality was generous, and helped to sustain an intellectual diet of discussion that was as intense as it was enjoyable, stimulating and indeed 'effervescent'.

Papers were given by Myron Achimastos, Antonis Geogoulas, Giannis Prelorentzos, Manos Savakis and Syprus Tegos, from Greece, Dmitri Lang, Patrice Maniglier and Philippe Steiner, from France, Giovanni Paoletti and Massimo Rosati, from Italy, John Brooks and Alexander Riley, from the USA,, and Nick Allen, Bill Pickering and Willie Watts Miller, from Britain. (Further details are on: aljira@social.soc.uol.gr)

The conference was dedicated to the memory of Philippe Besnard. At the same time it helped to mark the achievement of Myron Achimastos, in producing the first Greek translation and edition of Les formes élémentaires. As anyone involved in the tasks of translating and editing will be aware, this must have been a Herculean labour, requiring not only enormous scholarship and indomitable determination but fine judgement. Indeed, one of the most interesting sessions was on the problems and challenges of translating Durkheim-in particular his masterpiece, Les formes élémentairesinto other languages.

However, another achievement of Myron Achimastos has been to inspire a whole generation of young Greek scholars, as was strikingly evident in their contributions to the conference. It is very much to be hoped that a book in French or English will emerge, accessing some of all this to a wider audience. 


\section{Oxford}

\section{November 2003}

The British Centre for Durkheimian Studies held a study-day on 15 November 2003 at the Maison Française, Oxford. This was the first of the academic year, and was concerned with Durkheim and Parsons. Jean-Christophe Marcel (Paris) discussed the French critique of Parsons (cf. his article in our current issue). Ken Thompson (London) reviewed developments in Alexander's 'neo-Parsonian' Durkheimianism. Sue Stedman Jones (London) gave a paper on fundamental misinterpretations of Durkheim by Parsons, and Jonathan Fish (Leeds) followed with a qualified defence of Parsons (cf. his article in Journal of Classical Sociology 4 (1) 2004).

\section{February 2004}

The second study-day of the series was held on 28 February 2004. Mike Hawkins (Kingston) gave a paper reassessing the relationship between Durkheim and Spencer, and entitled 'Issues in morality in Durkheim and Spencer'. Due to an illness from which he has now fortunately recovered, Mike Gane (Loughborough) was unable to give his paper on Durkheim and Comte. But the day remained a full and successful one, with the paper by Philip Mellor (Leeds) on 'Durkheim as theorist of emergence'.

\section{June 2004}

The third study-day took place on 19 June, and was entitled Durkheim, Suffering and Evil. Massimo Rosati (Perugia) began with a paper on 'Durkheim, suffering and evil', Bill Pickering followed with 'Durkheim, Bauman and the Holocaust', and John Allock (Bradford) drew on his experience of events in the former Yugoslavia to discuss 'The Hague Tribunal seen in a Durkheimian mode'.

\section{Perugia}

\section{3-14 May 2004}

A conference was held on 13-14 May 2004, in the Department of Sociology the University of Perugia, entitled Rileggere Durkheim. Esperienza del tempo, categorie e solidarietà sociale. Papers were presented by Gianfranco Poggi, Massimo Rosati, Giovanni Paoletti, Ambrogio Santambrogio, and Filippo Zerilli. 